ryegrasses. Proceedings of the New Zealand Grassland Association 71: 187-193.

CSIRO (Ed.) 2007. Nutrient requirements of domesticated ruminants, Collingwood, Australia.

Edwards, G.R.; Bryant, R.H.; Smith, N.; Hague, H.; Taylor, S.; Ferris, A.; Farrell, L. 2015. Milk production and urination behaviour of dairy cows grazing diverse and simple pastures. Proceedings of the New Zealand Society of Animal Production 75: the New

Edwards, G.R.; Parsons, A.J.; Rasmussen, S. 2007. High sugar ryegrasses for dairy systems. Meeting the Challenges for Pasture-Based Dairying: 307-334.

Elgersma, A.; Hassink, J. 1997. Effects of white clover (Trifolium repens L.) on plant and soil nitrogen and soil organic matter in mixtures with perennial ryegrass (Lolium perenne L.). Plant and Soil 197: 177-186.

Hristov, A.; Ropp, J.; Grandeen, K.; Abedi, S.; Etter, R.; Melgar, A.; Foley, A. 2005. Effect of carbohydrate source on ammonia utilization in lactating dairy cows. Journal of Animal Science 83: 408-421.

Lee, J.; Hedley, P.; Roche, J. 2011. Grazing management: guidelines for optimal pasture growth and quality. DairyNZ Technical Series September: 6-10.

Martin, K.M.; Edwards, G.R.; Bryant, R.H.; Hodge, M.; Moir, J.; Chapman, D.F.; Cameron, K.C. 2017. Herbage dry-matter yield and nitrogen concentration of grass, legume and herb species grown at different nitrogen-fertiliser rates under irrigation. Animal Production Science: 57: 1283-1288. (doi:https://doi. org/10.1071/AN16455).

Miller, L.A.; Moorby, J.M.; Davies, D.R.; Humphreys, M.O.; Scollan, N.D.; MacRae, J.C.; Theodorou, M.K. 2001. Increased concentration of water-soluble carbohydrate in perennial ryegrass (Lolium perenne $L)$ : milk production from late-lactation dairy cows. Grass and Forage Science 56: 383-394.

Minneé, E.M.K.; Waghorn, G.C.; Lee, J.M.; Clark,
C.E.F. 2017. Including chicory or plantain in a perennial ryegrass/white clover-based diet of dairy cattle in late lactation: Feed intake, milk production and rumen digestion. Animal Feed Science and Technology 227: 52-61.

Moorby, J.M.; Evans, R.T.; Scollan, N.D.; MacRae, J.C. 2006. Increased concentration of water-soluble carbohydrate in perennial ryegrass (Lolium perenne L.). Evaluation in dairy cows in early lactation. Grass and Forage Science 61: 52-59.

Moot, D.J.; Brown, H.E.; Teixeira, E.I.; Pollock, K.M. 2003. Crop growth and development affect seasonal priorities for lucerne management. Grassland Research and Practice Series 11: 201-208.

Sanderson, M.A.; Labreveux, M.; Hall, M.H.; Elwinger, G.F. 2003. Nutritive value of chicory and English plantain forage. Crop Science 43: 1797-1804.

Tamminga, S. 1992. Nutrition management of dairy cows as a contribution of pollution control. Journal of Dairy Science 75: 345-357.

Tamminga, S. 1996. A review on environmental impacts of nutritional strategies in ruminants. Journal of Animal Science 74: 3112-3124

Tas, B.M.; Taweel, H.Z.; Smit, H.J.; Elgersma, A.; Dijkstra, J.; Tamminga, S. 2006. Utilisation of N in perennial ryegrass cultivars by stall-fed lactating dairy cows. Livestock Science 100: 159-168.

Totty, V.K.; Greenwood, S.L.; Bryant, R.H.; Edwards, G.R. 2013. Nitrogen partitioning and milk production of dairy cows grazing simple and diverse pastures. Journal of Dairy Science 96: 141-149.

Vibart, R.; Tavendale, M.; Burke, J.; Pacheco, D. 2012. In vitro fermentation of $[15 \mathrm{~N}-]$ ryegrass and ruminal digesta of sheep grazing a ryegrass-based pasture in the morning or in the afternoon. Proceedings of the New Zealand Society of Animal Production 72: 100-105.

Waghorn, G.C. 2002. Can forages match concentrate diets for dairy production? New Zealand Society of Animal Production 62: 261-266.

\title{
Variable and differential application of nutrients to a hill country
}

\section{farm}

J.D. MORTON and A.G. GILLINGHAM

MortonAg, 27 Waimakariri Drive, Napier 4110, New Zealand Research Consultant, 92 Waicola Drive, Palmerston North, New Zealand

mortonag@vodafone.co.nz

\section{Abstract}

Traditionally fertiliser has been aerially applied at a uniform rate to hill country, but the technology now exists to apply nutrients at a variable rate (VR) and each nutrient differentially, depending on the production potential and pasture composition of each part of the hill. A hypothetical case study of a sheep farm was modelled to show the economic benefits of VR application of phosphorus (P) and sulphur (S) and differential application of nitrogen (N), compared with application of a uniform rate of $\mathrm{P}$ and $\mathrm{S}$. The financial analysis demonstrates that the VR strategy of less P and $\mathrm{S}$ to steeper slopes where there is low legume and more on easier slopes where there is more legume, costs less than the application of $\mathrm{P}$ and $\mathrm{S}$ at a uniform rate over all slopes. The cost saving could be used to apply $\mathrm{N}$ to steep land on both sunny and shady aspects and easy land on sunny aspects. This differential $\mathrm{N}$ application in late winter/early spring ensures better pasture cover for lactating ewes to improve ewe condition at weaning. When this gain in condition was maintained through to mating, lambing percentage increased in the following spring. The benefit from this increased lamb production was an increase in financial returns of $\$ 63 / \mathrm{ha} /$ year. A qualitative sensitivity analysis indicated that this value remains stable in response to changes in the proportion of each slope class, soil Olsen P level, the relative cost of fertiliser $\mathrm{P}$ and $\mathrm{N}$ and sheep to cattle ratio.

Keywords: differential application, hill country, lamb production, nitrogen, phosphorus, aerial topdressing, variable rate

Terminology

Variable rate (VR) fertiliser application occurs when the same nutrients, normally $\mathrm{P}$ and $\mathrm{S}$, are flown onto an area at different rates according to the production potential and stocking rate of each slope class. The slope ranges of the area were identified using a Digital Elevation Map, and quadrats (normally representing not less than 0.5 ha) are allocated one slope class in a prescription map, if they have the largest proportion of the area within that class (Morton et al. 2016).

Differential nutrient application occurs when one fertiliser nutrient, usually $\mathrm{N}$, is applied to certain parts of the farm, usually steep slopes or sunny aspects where the pasture production response is greatest (Gillingham et al. 1998).

\section{Introduction}

Fertiliser is a discretionary cost in a sheep and beef farm budget and is frequently reduced in years where income is limited by poor returns or adverse climatic events. With the prospect of no consistent inflationadjusted increase in meat and wool prices, the only way of ensuring that adequate fertiliser is applied is to improve the efficiency of nutrient use. While fertiliser has been traditionally spread at a uniform rate, the aircraft technology now exists to apply nutrients both at a variable rate and differentially to different parts of a hill country farm, depending on production potential and pasture composition (Murray \& Yule 2007; Morton et al. 2016; White et al. 2017)

Nearly all hill country requires $\mathrm{P}$ and $\mathrm{S}$ to sustain legume and pasture growth $A$ uniform application rate -match between the variable requirement of the pasture, depending on production potential that determines stocking rate, and the uniform ates traditionally applied in fertiliser (Gillingham et al. 1998). Variable rate application allows fertiliser $P$ and $\mathrm{S}$ rates to be adjusted, usually on the basis of slope, which is the main determinant of pasture production (Lambert et al. 1983); flatter areas with better legume growth receiving more than steeper areas with poorer legume growth.

Several trials have shown a high efficiency of response in pasture production to fertiliser $\mathrm{N}$ in hill country, especially on steeper slopes with less soil $\mathrm{N}$ (Morton et al. 2016).

This paper investigates the economic benefits of VR and differential nutrient application, by applying them optimally to a case study hill sheep farm in a modelling exercise.

\section{Methodology}

The case study farm had a total area of 600 ha -200 ha of flat within the hill landscape, 200 ha of easy hill (12-25 degree slope) comprising 100 ha each of sunny (north and west aspects) and shady (south and eas aspects), and 200 ha of steep hill (>26 degrees slope) comprising 100 ha each of sunny and shady aspect, all on sedimentary soils with adequate soil potassium. 
Average rainfall was $1000 \mathrm{~mm} /$ year with a lack of soil moisture during summer, typical of a North Island dry hill country farm. For simplicity, the farm carried all sheep, but the inclusion of cattle was considered in the qualitative sensitivity analysis. It was also assumed for simplicity, that most of the non-productive areas on the farm were being avoided by the uniform application fertiliser programme, so there is no cost saving from the ability of VR application to more accurately achieve this objective.

The approximate 3:2:1 ratio in relative stocking rate between land classes in Table 1, was assumed from different studies of pasture productivity on contrasting slopes (Morton et al. 2016). Soil Olsen P levels for each land class were within (flat and easy) or above (steep) the economic optimal ranges as modelled by the AgResearch PKS Lime model. The average annual pasture composition was based on a long-term hill country grazing trial at Ballatre (Lambert et al. 1986). A qualtative sensitivity ansis for od. scenarios (Table 4) was mainly based on knowledge gained from earlier research on the responses in pasture production from $\mathrm{P}$ and $\mathrm{N}$ in relation to slope, aspect and soil Olsen P level (e.g. Gillingham et al. 1998, 2003 , 2017).

\section{Fertiliser programme}

Uniform app

Uniform application was the annual routine programme of maintenance application in spring to supply $18 \mathrm{~kg}$ P and $22 \mathrm{~kg} \mathrm{~S} /$ ha over the whole farm. $V R$ and differential nutrient application

With this programme, the maintenance $\mathrm{P}$ and $\mathrm{S}$ applications have been chosen on the basis of the pasture growth required to support the different stocking rates (Table 1) on each slope and aspect type. This meant the 200 ha of land that was predominantly flat within the hill couly las $\mathrm{kg} \mathrm{P}$ and $22 \mathrm{~kg} \mathrm{~S} / \mathrm{ha}$; the 100 ha of predominantly

shady easy land received $15 \mathrm{~kg} \mathrm{P}$ and $18 \mathrm{~kg} \mathrm{~S} / \mathrm{ha}$ year; the 100 ha of predominantly sunny easy land received $30 \mathrm{~kg} \mathrm{~N}, 12 \mathrm{~kg} \mathrm{P}$ and $20 \mathrm{~kg} \mathrm{~S} / \mathrm{ha}$; the 100 ha of predominantly shady steep land received $30 \mathrm{~kg}$ $\mathrm{N} / \mathrm{ha}$ applied one year and $30 \mathrm{~kg} \mathrm{~N}, 12 \mathrm{~kg} \mathrm{P}$ and 20 $\mathrm{kg} \mathrm{S} / \mathrm{ha}$ in the second year, providing an annual rate of $6 \mathrm{~kg} \mathrm{P}$ and $7 \mathrm{~kg} \mathrm{~S} / \mathrm{ha}$; the 100 ha of predominantly sunny steep land received $30 \mathrm{~kg} \mathrm{~N} / \mathrm{ha}, 2$ years out of three, and in the third year had $30 \mathrm{~kg} \mathrm{~N}, 12 \mathrm{~kg}$ and $15 \mathrm{~kg}$ S/b aplied. As for the shaty steep $15 \mathrm{~kg}$ S/ha applied. As for the shady steep land, this sustains the low legume content (Table 1)

If ground conditions do not allow application of $\mathrm{N}$ at the optimal time of late winter/early spring and there was a serious feed deficit in early spring, then a more expensive helicopter operation could be carried out for $\mathrm{N}$, and the $\mathrm{P}$ and $\mathrm{S}$ applied later

\section{Comparative experimental data}

The Waipawa Research Area provided data (Table 2) as it represents a similar scenario to the case study farm. Morton et al. (2016) deduced from a review of the literature on $\mathrm{N}$ responses in hill country, that the efficiency of $\mathrm{N}$ use for slopes of $15-35^{\circ}$ was $26 \mathrm{~kg}$ DM/ $\mathrm{kg} \mathrm{N}$. Under higher annual mean rainfall of $1426 \mathrm{~mm}$ at Whatawhata Research Station, Gillingham (2017) also measured a higher efficiency of P use on easy (595 kg DM/kg P) compared with steep (337 kg DM/ $\mathrm{kg}$ P) slopes receiving $20 \mathrm{~kg} \mathrm{P} / \mathrm{ha} /$ year. At Ballantrae Research Station, with a slightly lower annual rainfall (1276 mm) Lambert et al. (1983) measured efficiencies of P use of 408, 296 and $217 \mathrm{~kg} \mathrm{DM} / \mathrm{kg}$ P for flat, easy and steep land, respectively, receiving an average of 29 $\mathrm{kg} \mathrm{P} / \mathrm{ha} /$ year.

\section{Financial analysis}

Fertiliser cost

In Table 3, the cost of ground applied fertilisers averaged over land classes is presented. It was assumed that transport of fertiliser to the farm was $\$ 30 /$ tonne,

Table 1 Stocking rate (SU/ha), soil Olsen P $(\mu \mathrm{g} / \mathrm{ml})$ and percentage of total pasture composition for each land class.

\begin{tabular}{lccccc}
\hline $\begin{array}{l}\text { Land class } \\
\text { (slope/aspect) }\end{array}$ & $\begin{array}{c}\text { Stocking } \\
\text { rate }\end{array}$ & $\begin{array}{c}\text { Soil Olsen } \\
\text { P }\end{array}$ & & \multicolumn{3}{c}{ Percentage of total pasture composition } \\
\cline { 4 - 6 } & & & $\begin{array}{c}\text { High fertility demanding } \\
\text { grasses e.g. ryegrass, } \\
\text { cocksfoot }\end{array}$ & $\begin{array}{c}\text { Low fertility demanding } \\
\text { grasses e.g. browntop, } \\
\text { sweet vernal, crested } \\
\text { dogstail }\end{array}$ & $\begin{array}{c}\text { Legumes e.g. white } \\
\text { and subterranean clover }\end{array}$ \\
\hline Flat & 16 & $20-25$ & 45 & 45 & 10 \\
Shady easy & 12 & $15-20$ & 23 & 70 & 7 \\
Sunny easy & 10 & $15-20$ & 17 & 76 & 7 \\
Shady steep & 6 & $10-15$ & 10 & 85 & 5 \\
Sunny steep & 5 & $10-15$ & 5 & 90 & 5 \\
\hline
\end{tabular}

uniform aerial application costs $\$ 70 /$ tonne and variable rate application $\$ 85 /$ tonne

The total applied fertiliser costs are similar for uniform versus variable rate and differential application (Table 3). The VR programme applied less $\mathrm{P}$ and $\mathrm{S}$ which makes finance available to include $\mathrm{N}$ which is approximately half the cost per $\mathrm{kg}$ of $\mathrm{P}$.

\section{Financial returns}

Because the VR programme closely matches specific pasture species requirements for $\mathrm{P}$ and $\mathrm{S}$ (legumes $>$ ryegrass $>$ browntop) and stocking rate of each land class, it should achieve similar pasture production to that arising from the application of a uniform fertiliser rate considered appropriate for the

Table 2 Referenced responses in nutrient use efficiency from grazing trials at Waipawa Research Area and lamb liveweights and gross margins per hectare from a simulation study.

\begin{tabular}{|c|c|c|c|c|c|}
\hline Parameter & & arison & & & Reference \\
\hline Efficiency of $P$ use & Easy slope & Steep slope & $\begin{array}{c}\text { Easy - } 128 \mathrm{~kg} \\
\mathrm{DM} / \mathrm{kg} \mathrm{P}\end{array}$ & $\begin{array}{l}\text { Steep - } 66 \mathrm{~kg} \\
\mathrm{DM} / \mathrm{kg} P\end{array}$ & $\begin{array}{l}\text { Gillingham } \\
\text { et al. } 1998\end{array}$ \\
\hline Efficiency of $\mathrm{N}$ use & $\begin{array}{l}\text { Easy sunny } \\
\text { slope }\end{array}$ & $\begin{array}{l}\text { Steep sunny } \\
\text { and shady slope }\end{array}$ & $\begin{array}{c}\text { Easy - } 17 \mathrm{~kg} \\
\mathrm{DM} / \mathrm{kg} \mathrm{N}\end{array}$ & $\begin{array}{l}\text { Steep - } 35 \mathrm{~kg} \\
\text { DM } / \mathrm{kg} \mathrm{N}\end{array}$ & $\begin{array}{l}\text { Gillingham } \\
\text { et al. } 2003\end{array}$ \\
\hline Lamb liveweight & No N & $\begin{array}{l}30 \mathrm{~kg} \mathrm{~N} / \mathrm{ha} \text { with } \\
\text { same ewe stocking rate }\end{array}$ & No N - $139 \mathrm{~kg} / \mathrm{ha}$ & $\mathrm{N}-207 \mathrm{~kg} / \mathrm{ha}$ & $\begin{array}{l}\text { Gillingham } \\
\text { et al. } 2003\end{array}$ \\
\hline Gross margin & No N & $\begin{array}{c}30 \mathrm{~kg} \mathrm{~N} / \mathrm{ha} \text { with } \\
\text { same stocking rate }\end{array}$ & No N - $\$ 557 /$ ha & $\mathrm{N}-\$ 642 / \mathrm{ha}$ & $\begin{array}{l}\text { Gillingham } \\
\text { et al. } 2003\end{array}$ \\
\hline
\end{tabular}

Table 3 Applied fertiliser costs for each land class.

\begin{tabular}{|c|c|c|c|c|c|}
\hline Land class & Fertiliser & $\begin{array}{l}\text { Fertiliser } \\
\operatorname{cost}(\$)\end{array}$ & $\begin{array}{l}\text { Transport } \\
\text { cost (\$) }\end{array}$ & $\begin{array}{l}\text { Application } \\
\text { cost (\$) }\end{array}$ & $\begin{array}{c}\text { Total } \\
\operatorname{cost}(\$)\end{array}$ \\
\hline \multicolumn{6}{|l|}{ Uniform application } \\
\hline Whole farm (600 ha) & Superphosphate $(0-9-0-11)-120 t$ & 40200 & 3600 & 8400 & 52200 \\
\hline \multicolumn{6}{|c|}{ VR and differential application } \\
\hline Flat (200 ha) & Superphosphate $(0-9-0-11)-40 t$ & 13400 & 1200 & 3400 & 18000 \\
\hline Shady easy (100 ha) & Superphosphate $(0-9-0-11)-20 t$ & 6700 & 600 & 1700 & 9000 \\
\hline Sunny easy (100 ha) & Cropmaster 20* $(19-10-0-13)-15 t$ & 10500 & 450 & 1275 & 12225 \\
\hline \multirow[t]{3}{*}{ Shady steep (100 ha) } & Urea $(46-0-0-0)$ for one year $-6.5 \mathrm{t}$ & 3250 & 195 & 553 & 4000 \\
\hline & $\begin{array}{l}\text { Cropmaster } 20(19-10-0-13) \\
\text { for other year - } 15 \mathrm{t}\end{array}$ & 10500 & 450 & 1275 & 1222 \\
\hline & Average per year & & & & 8110 \\
\hline \multirow[t]{3}{*}{ Sunny steep (100 ha) } & Urea $(46-0-0-0)$ for two years $-13 t$ & 6500 & 390 & 1105 & 7995 \\
\hline & $\begin{array}{l}\text { Cropmaster } 20(19-10-0-13) \\
\text { for the third year }-15 \mathrm{t}\end{array}$ & 10500 & 450 & 1275 & 12225 \\
\hline & Average per year & 6300 & 280 & 793 & 6740 \\
\hline \multicolumn{5}{|c|}{ Total cost for VR and differential application } & 54075 \\
\hline
\end{tabular}

*The approximate equivalent fertiliser supplied by Ballance is Pasture Zeal G2 Impact (12-6-0-7), priced at \$430/tonne.

average stocking rate. The production advantage from VR and differential application was the extra feed generated from the $\mathrm{N}$ fertiliser. The calculations used are as follows:

Detrom $=300$ ha $\times 30 \mathrm{~kg} \mathrm{~N} / \mathrm{h}$ (2) $6000 \mathrm{SU}$ on this farm translates into another $31 \mathrm{~kg} \mathrm{DM}$ U consumed.

If $1 \mathrm{~kg}$ of liveweight gain requires $5 \mathrm{~kg}$ DM consumed each ewe would be expected to be about $6 \mathrm{~kg}$ heavier at weaning and mating, resulting in an increase in lambing percentage of $8 \%$ (or $7 \%$ at sale allowing for losses of

5\%) (Geenty 1997); for $6000 \mathrm{SU}$ this represents an 
extra 420 lambs, at say $\$ 90 /$ lamb, equivalent to $\$ 38000$ or $\$ 63 /$ ha/year.

Although the value is not a true gross margin as the costs associated with rearing and finishing the extra lambs have not been included, it is still lower than the increase in gross margin from $\mathrm{N}$ use included in Table 2 (Gillingham et al. 2003). However, these authors assumed a much larger increase in lambing percentage (from 120 to $165 \%$ ), resulting in an increase of $68 \mathrm{~kg} /$ ha of lamb liveweight (Table 2), than occured in this analysis.

\section{Other uses of extra finance}

If there was no desire or need to apply N, then the savings in $\mathrm{P}$ and $\mathrm{S}$ application from VR compared with uniform application (about $\$ 10000 /$ year) could be used to apply $\mathrm{P}$ to areas of the farm with soil Olsen P levels below the economic optimum or for lime application.

\section{Qualitative sensitivity analysis}

The main variables that potentially affect the financial benefit from this VR and differential nutrient strategy compared with uniform application are the proportion of farm in each slope class, soil Olsen P levels, the comparative cost of $\mathrm{P}$ and $\mathrm{N}$ and the sheep to cattle ratio (Table 4).

The analysis shows that changes in the major variables affecting financial performance have a neutra to positive effect. Murray \& Yule (2007) also reported that the cash surplus/ha was inelastic to increasing application costs from VR.

The case study farm example outlined in this paper is

only one of a multitude of farm scenarios that could be tested. Murray \& Yule (2007) calculated that the cash surplus increased from $\$ 386$ to $\$ 487 /$ ha when changing from a blanket application of superphosphate to VR for a hill country farm case study. Morton et al (2016) estimated a greater net margin from VR than uniform application at lower rather than higher soil Olsen $\mathrm{P}$ levels from a single year of analysis. White \& Roberts (2107) used the AgResearch PKS Lime model for 10 set Present Value to VR compared with uniform application, on farms with optimal soil Olsen P levels.

\section{Conclusions}

The current policy of uniform fertiliser application to hill country sheep and beef farms is inefficient as it applies more $\mathrm{P}$ and $\mathrm{S}$ than is required to sunny and steep areas, where lack of moisture limits legume and pasture growth. Variable rafe application technology allows $P$ and $\mathrm{S}$ to be applied at closer to the required rates for hill areas depending on legume content and stocking rate. Less $\mathrm{P}$ and $\mathrm{S}$ to steeper land that lack legumes allows cheaper differential $\mathrm{N}$ to be substituted, resulting in large economic pasture production responses to $\mathrm{N}$. This extra feed can be used to increase ewe weaning liveweights that can be maintained through to mating with improved ovulation rates increasing the number of lambs sold in the following year. Alternatively, the saving from VR, compartict $\mathrm{P}$ and $\mathrm{S}$, can be used for targeted $\mathrm{P}$ or lime applications. For this case study farm, the costs of the uniform compared with the VR and differential nutrient applications were similar, so the extra $\$ 63 /$ ha/year gained from the differential $\mathrm{N}$ application represents profit.

\section{ACKNOWLEDGEMENTS}

Thanks are due to all the research, farming and aircraft personnel who developed the new aerial application technologies and opened a new profitable path for farmers.

\section{REFERENCES}

Geenty, K.G. 1997. A guide to improved lambing percentage for farmers and advisors. Wools of New Zealand and Meat Producers Board, Palmerston North, New Zealand. 128 pp.

Gillingham, A.G.; Gray, M.H.; Smith, D. 1998. Pasture responses to phosphorus and nitrogen fertiliser on dry hill country. Proceedings of the New Zealand Grassland Association 60: 135-140.

Gillingham, A.G.; Sheath, G.W; Gray, M.H.; Webby, R.W. 2003. Management and nitrogen fertiliser options for improved pasture productivity in dryland hill systems. Grassland Research and Practice Series 11: 43-49.

Gillingham, A.G. 2017. Phosphate fertiliser application effects on seasonally dry hill country pasture and soil. New Zealand Journal of Agricultural Research 59: 280-300.
Lambert, M.G.; Clark D A.; Grant D. A ; Costall D.A.; Fletcher, R.H. 1983. Influence of fertilise and grazing management on North Island moist hil country. 1. Herbage accumulation. New Zealand Journal of Agricultural Research 26: 95-108.

Lambert, M.G.; Clark, D.A.; Grant, D.A.; Costall, D.A. 1986. Influence of fertiliser and grazing management on North Island moist hill country. 2. Pasture botanical composition. New Zealand Journal of Agricultural Research 29: 1-10.

Morton, J.D : Stafford, A.D; Gillingham, A.G.; Old, A.; Knowles, O. 2016. The development of variable rate application of fertiliser from a fixed wing topdressing aircraft. Grassland Research and Practice Series 16 163-167.

Murray, R.I.; Yule, I.J. 2007. Developing variable rate application technology: economic impact for farm owners and topdressing operators. New Zealand Journal of Agricultural Research 50: 65-72.

White, J.M. Roberts, A.H.C. 2017. The use of variable rate application fertiliser in New Zealand hill country. In: Science and policy: nutrient management challenges for the next generation. Eds. Currie L.D.; Hedley M.J. Occasional Report No. 30. Fertilizer and Lime Research Centre, Palmerston North, New Zealand. 13 pp. http://flrc/massey.ac.nz.publications. html. Table 4 Qualitative sensitivity analysis for changes in variables affecting financial benefit from VR and differential nutrient

\begin{tabular}{lll}
\hline Change in variable & $\begin{array}{l}\text { Effect on financial } \\
\text { benefit }\end{array}$ & Explanation \\
\hline $\begin{array}{l}\text { Increasing proportion of flat land } \\
\text { and decreasing proportion of } \\
\text { steeper land or vice versa }\end{array}$ & A small effect & $\begin{array}{l}\text { Although cost of VR will increase because more expensive P is } \\
\text { required, stocking rate and production will also increase, } \\
\text { offsetting the cost. Where there is steeper land, fertiliser costs } \\
\text { will be lower but also will production }\end{array}$ \\
\hline $\begin{array}{l}\text { Lower than economic } \\
\text { optimum Olsen P levels }\end{array}$ & $\begin{array}{l}\text { Lower benefit in the } \\
\text { short-term because of } \\
\text { capital P required, but } \\
\text { higher in longer term } \\
\text { as benefits accrue }\end{array}$ & $\begin{array}{l}\text { Initial cost of capital P will be regained and profitability } \\
\text { increased over time from more pasture production }\end{array}$ \\
\hline $\begin{array}{l}\text { Higher than economic } \\
\text { optimum Olsen P levels }\end{array}$ & Greater benefit overall & $\begin{array}{l}\text { P rates can be reduced over all the farm resulting in saving in } \\
\text { fertiliser costs }\end{array}$ \\
\hline $\begin{array}{l}\text { Change in cost of } \\
\text { fertiliser P relative to N }\end{array}$ & Unlikely to be a factor & $\begin{array}{l}\text { Pricing history shows that cost of } \mathrm{N} \text { and P changes in a largely } \\
\text { similar pattern }\end{array}$ \\
\hline Inclusion of cattle & Small effect & $\begin{array}{l}\text { Cattle performance will also benefit from greater pasture growth } \\
\text { during spring }\end{array}$ \\
\hline
\end{tabular}

